\title{
Dampak Spasial Komunitas Berpagar terhadap Kawasan Perkotaan Mamminasata
}

\author{
The Spatial Impact of Gated Communities on the Mamminasata Urban Area
}

\author{
Pratiwi Ramli ${ }^{1}$, Petrus N. Indradjati ${ }^{1}$
}

Diterima: 1 Desember 2019 Disetujui: 8 Mei 2020

\begin{abstract}
Abstrak: Kajian dampak komunitas berpagar di Indonesia seringkali fokus pada aspek sosial. Sementara dampak spasial yang berkontribusi pada perubahan struktur dan pola ruang masih sangat terbatas. Penelitian ini bertujuan untuk mengidentifikasi dampak spasial dari aspek transformasi spasial, fragmentasi spasial, serta perubahan infrastruktur, fasilitas dan layanan akibat perkembangan komunitas berpagar di Kawasan Perkotaan Mamminasata. Penelitian ini bersifat deskriptif-explanatori dengan pendekatan evaluasi semu pada 392 komunitas berpagar yang teridentifikasi di Kawasan Perkotaan Mamminasata. Hasil penelitian menunjukkan bahwa perkembangan komunitas berpagar menyebabkan terjadinya transformasi spasial karena mendorong perkembangan fisik yang menyebar, tidak berpola, tidak teratur serta mendorong perubahan guna lahan yang signifikan. Fragmentasi ruang terjadi di lapangan karena mayoritas komunitas berpagar di kelilingi pagar/tembok serta memiliki akses terkontrol, namun pelarangan penggunaan fasilitas publik di dalam komunitas berpagar tidak terjadi. Dari aspek infrastruktur, keberadaan komunitas berpagar tidak selalu menyebabkan kualitas infrastruktur lingkungan di sekitarnya lebih baik dari sebelumnya.
\end{abstract}

\section{Kata Kunci: Dampak spasial, komunitas berpagar, metropolitan, Mamminasata}

\begin{abstract}
An impact assessment of gated communities in Indonesia often focuses on social aspects. While spatial impacts that contribute to changes in spatial structure and patterns are still very limited. This study aims to identify spatial impacts from three following aspects, namely spatial transformation, spatial fragmentation, and changes in infrastructure, facilities and services due to the development of gated communities in the Mamminasata Urban Area. This research is a descriptive explanatory with a pseudo evaluation approach to 392 identified gated communities in the Mamminasata Urban Area. The results showed that the development of gated communities led to spatial transformation because it encouraged physical development that spreads not patterned and irregular. The development leads to significant land use changes. Fragmentation of space occurs because many gated communities are surrounded by gates/walls and controlled access, but the prohibition of the use of public facilities in gated communities does not occur. From the aspect of infrastructure, the existence of a gated community does not always lead to a better quality of the surrounding environmental infrastructure.
\end{abstract}

Keywords: Spatial impacts, gated communities, metropolitan, Mamminasata

1 Sekolah Arsitektur, Perencanaan dan Pengembangan Kebijakan, Institut Teknologi Bandung

Korespondensi: natalivan@ sappk.itb.ac.id 


\section{PENDAHULUAN}

Komunitas berpagar dapat diartikan sebagai suatu permukiman yang terpisah dari lingkungan sekitarnya dikelilingi oleh dinding pagar untuk mengendalikan, memantau dan membatasi akses (Blakely \& Snyder, 1997; Elhadary \& Ali, 2017). Fitur utama dari permukiman ini adalah adanya dinding pagar yang mengelilingi kawasan sehingga penghuni atau tamu, tidak dapat leluasa keluar masuk kawasan dengan bebas tanpa minta izin atau memiliki kartu anggota di pintu penjagaan. Blakely \& Snyder (1997) juga menjelaskan bahwa komunitas berpagar merupakan daerah perumahan dengan akses terbatas, di mana ruang yang biasanya dapat diakses oleh publik dibuat menjadi privat. Karakteristik perumahan ini menjadi popular sebagai salah satu bentuk transformasi sistem perumahan dari model penyediaan perumahan oleh pemerintah ke model penyediaan oleh pasar (Song \& Liu, 2017). Sementara Yönet menganggap bahwa komunitas berpagar merupakan produk atau implikasi dari globalisasi (Yönet \& Yirmibeş oğ lu, 2018). Terdapat tiga tipe dari komunitas berpagar yaitu: tipe gaya hidup (lifestyle), harga diri (prestige), dan tipe keamanan lingkungan (Grant \& Mittelsteadt, 2004). Komunitas berpagar tipe gaya hidup umumnya merupakan permukiman para pensiunan, permukiman dengan padang golf, permukiman resort, ecohouse, dengan lingkungan yang mewah. Tipe harga diri berkarakteristik permukiman mewah dengan fasilitas yang serba eksklusif bagi masyarakat ekonomi atas yang mengutamakan citra, privasi, dan kontrol, biasanya dihuni oleh setidaknya kelompok menengah dan terkenal, eksekutif, selebriti dimana akses ke lingkungannya dikontrol. Permukiman tipe ini menyediakan rumah besar, halaman luas, lingkungan hijau, jalan teratur, serta fasilitas bersama yang lengkap. Tipe zona keamanan lingkungan bercirikan permukiman yang diberi pagar keliling dalam berbagai bentuk seperti pagar dari kawat duri, portal, maupun tembok yang mencerminkan rasa takut. Permukiman atau perumahan ini mempunyai akses publik terbatas mempunyai pagar untuk mencegah kejahatan atau membatasi lalu lintas dan gerbang di jalan umum serta barikade menutup akses ke beberapa jalan menuju ke lingkungan perumahan (Blakely \& Snyder, 1997). Tipologi lainnya ada yang didasarkan pada bentuk bangunan dalam lingkungan perumahan tersebut seperti komunitas berpagar dengan bangunan rumah horizontal, vertikal dan campuran keduanya (Al_Omari, 2015).

Komunitas berpagar di Kawasan Mamminasata berkembang cukup pesat terutama di kawasan pinggiran kota, peralihan kawasan perdesaan ke kawasan perkotaan terlihat cukup jelas. Beberapa penelitian yang dilakukan di Kawasan Perkotaan Mamminasata (Heryanto, 2013; Radhinal \& Ariyanto, 2017; Widiatri, 2014; Widiatri et al., 2014) menunjukkan polarisasi sosial di lingkup perdesaan semakin memperkuat munculnya ketegangan sosial yang terjadi di mana tempat tinggal yang semakin terfragmentasi menciptakan kelompok masyarakat yang berbeda berdasarkan kualifikasi pribumi dan pendatang, orang lama dan baru, serta orang kota dan orang desa. Fragmentasi fisik ini dalam perkembangan lebih lanjut menyebabkan terjadinya segregasi sosial sebagai sumber ketegangan bahkan konflik sosial dalam masyarakat selain konflik nilai tanah yang menyebabkan pasar tanah yang menjadi rentan dipersengketakan (Widiatri, 2014). Selain itu dampak ekonomi juga berpengaruh terhadap kenaikan harga tanah dan properti di sekitar komunitas berpagar (Heryanto, 2013) serta membuka peluang bagi masyarakat luar Komunitas untuk bekerja di dalam Komunitas berpagar tersebut. Demikian juga dengan penelitian yang dilakukan oleh Roitman dan Recio di Jakarta dan Yogyakarta, menunjukkan hubungan antara ketimpangan dan berkembangnya komunitas berpagar yang saling mempengaruhi, berakibat semakin meningkatnya perbedaan (ketimpangan) dan ketegangan sosial (Roitman \& Recio, 2019).

Penelitian terkait dampak komunitas berpagar terhadap spasial telah dilakukan di beberapa negara seperti Amerika, Kenya, Johannesburg, Sao Paulo dan Qatar (Le Goix, 
2005; Mahgoub \& Khalfani, 2012; Rafiq, 2015; Silva de Araujo \& Pereira de Queiroz, 2018). Beberapa penelitian tersebut menunjukkan bahwa komunitas berpagar dapat berdampak positif seperti mendorong fasilitas dan infrastruktur yang lebih baik, namun demikian mayoritas mengungkapkan bahwa komunitas berpagar menyebabkan sprawl serta terfragmentasinya kota. Di Indonesia sendiri penelitian terkait dampak spasial komunitas berpagar masih terbatas, khususnya dalam konteks wilayah Metropolitan. Penelitian terkait perubahan fisik spasial dalam lingkup kecil pernah dilakukan dengan lokasi penelitian di Jalan Tun Abdul Razak yang berubah karena perluasan wilayah perkotaan akibat adanya gagasan konsep Metropolitan Mamminasata (Radhinal \& Ariyanto, 2017). Kontribusi pengembang dalam hal ini erat kaitannya dengan penguasaan lahan yang ditandai dengan pemanfaatan ruang untuk kegiatan pembangunan sehingga keberadaan perumahan (real estate) yang dibangun berdampak sangat besar terhadap perubahan fisik spasial kawasan. Oleh karena itu, penelitian ini penting dilakukan untuk mengekplorasi karakteristik, pola sebaran serta mengetahui sejauh mana dampak spasial komunitas berpagar terhadap Kawasan Perkotaan Mamminasata.

\section{METODE}

Penelitian ini dilakukan pada lingkup wilayah Perkotaan Mamminasata. Luas wilayah Mamminasata adalah $2.462,3 \mathrm{~km}^{2}(246.230 \mathrm{ha})$ yang terbagi menjadi Kota Makassar (181 $\left.\mathrm{km}^{2}\right)$ Kabupaten Maros $\left(1.039 \mathrm{~km}^{2}\right)$, Kabupaten Gowa $\left(723 \mathrm{~km}^{2}\right)$ dan Kabupaten Takalar $\left(519 \mathrm{~km}^{2}\right.$ ). Penelitian ini menggunakan pendekatan evaluasi semu (pseudo evaluation) untuk mengidentifikasi dampak spasial komunitas berpagar. Metode pengumpulan data dalam penelitian ini berdasarkan data primer dan sekunder. Data primer didapatkan melalui observasi lapangan yang dilaksanakan pada bulan Januari 2019 hingga Maret 2019. Observasi lapangan dilakukan untuk plotting sebaran titik komunitas pada peta, kemudian melakukan pengecekan komunitas berpagar, infrastruktur dan fasilitas yang ada di dalam serta sekitar keberadaan komunitas berpagar. Dalam mengidentifikasi titik sebaran, alat yang digunakan adalah peta citra satelit yang kemudian diitegrasikan ke dalam perangkat lunak Arcgis untuk membuat peta sebaran komunitas berpagar. Wawancara semi terstruktur dilakukan dengan narasumber di antaranya: BKSPMM (Badan Kerjasama Pengembangan Metropolitan Mamminasata), Dinas Perumahan, Kawasan Permukiman dan Pertanahan Provinsi Sulawesi Selatan, Badan Perencanaan Pembangunan Daerah Provinsi Sulawesi Selatan, Dinas Tata Ruang Provinsi Sulawesi Selatan serta Dinas Penataan Ruang Kota Makassar. Selain itu wawancara juga dilakukan pada beberapa masyarakat yang tinggal didalam Komunitas berpagar dan perwakilan developer perumahan di Makassar. Data sekunder di dapatkan melalui review atau sintesis dari dokumen perencanaan, buku dan jurnal. Pengumpulan data sekunder terkait dengan karakteristik komunitas berpagar dan dampak spasial menggunakan literatur dari laporan penelitian atau jurnal. Dokumen perencanaan digunakan untuk melihat karakteristik Kawasan Perkotaan Mamminasata.

Analisis yang digunakan pada penelitian ini berupa: (1) analisis isi yang digunakan untuk menentukan karakteristik, indikator dan kriteria komunitas berpagar berdasarkan kajian literatur; (2) Analisis statistik deskriptif dilakukan untuk mendeskripsikan karakteristik Kawasan Perkotaan Mamminasata (data sosial, ekonomi, dan guna lahan), profil Komunitas berpagar serta analisis dampak spasial (perubahan guna lahan) di Mamminasata; (3) Analisis spasial dilakukan untuk menggambarkan sebaran, pertumbuhan/perkembangan komunitas berpagar, serta sebaran fasilitas dan layanan secara spasial. Analisis ini menggunakan citra satelit serta menggunakan alat untuk mengolah/menganalisis peta menggunakan Arcgis 10.3. Kriteria dan indikator dampak spasial dirumuskan berdasarkan kajian literatur, terdiri atas kriteria transformasi dan 
fragementasi spasial serta kriteria perubahan Infrastruktur, fasilitas dan layanan sebagaimana tercantum dalam Tabel 1 berikut.

Tabel 1. Kriteria dan Indikator Dampak Spasial Komunitas Berpagar

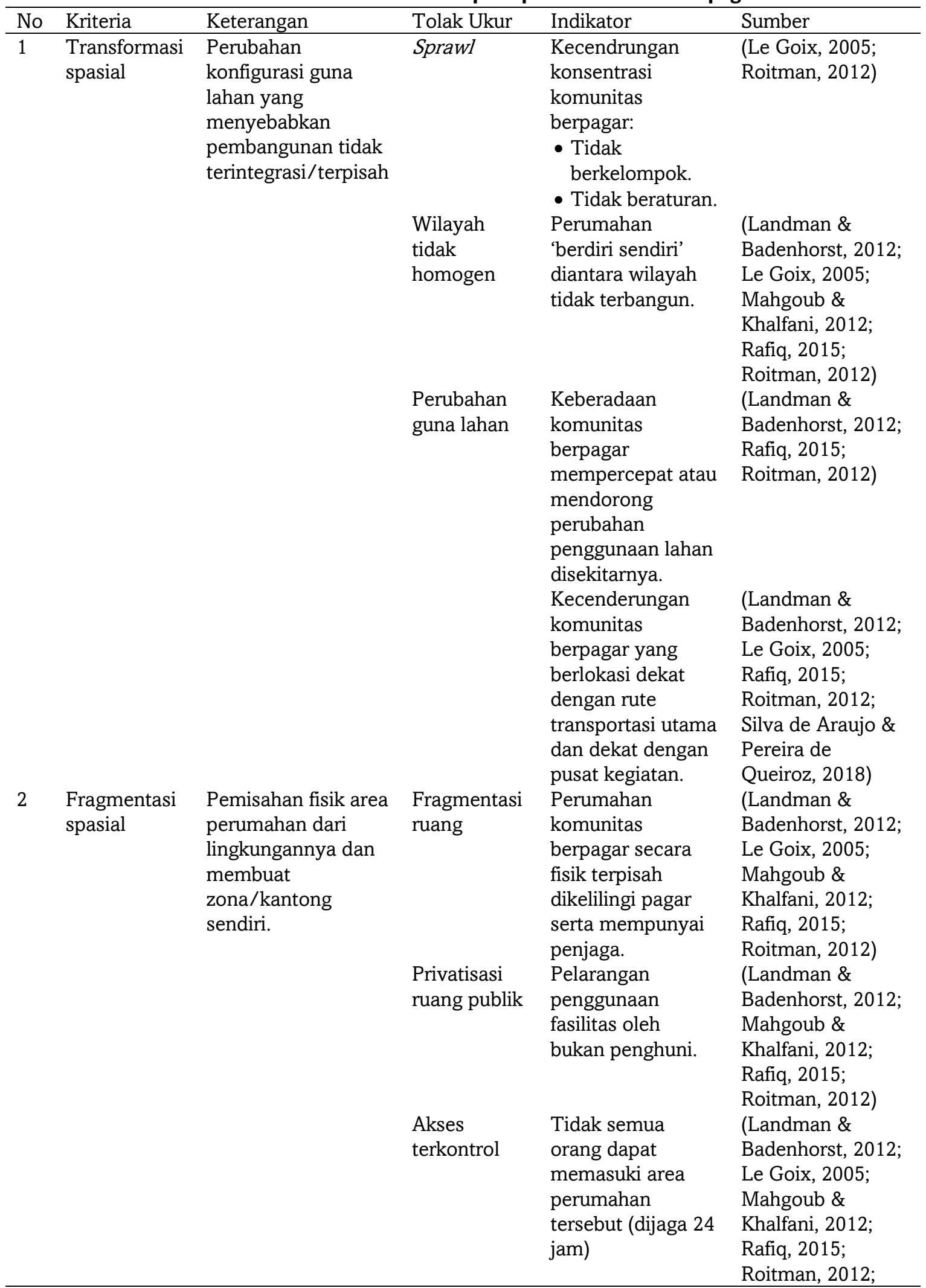




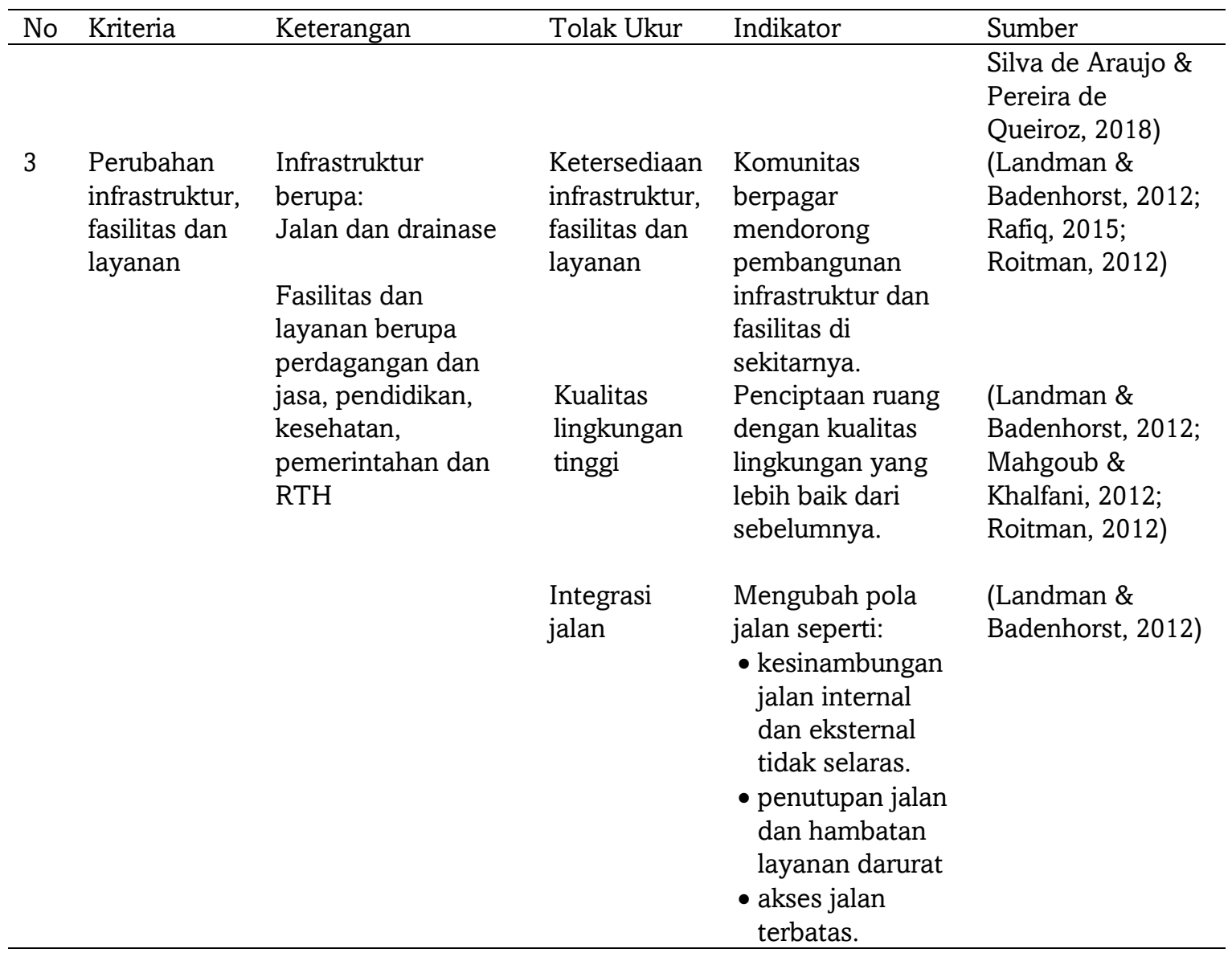

\section{HASIL DAN DISKUSI}

Perkembangan Kota Makassar dan wilayah sekitarnya yang cepat dan mobilitas penduduk yang tidak hanya terbatas di Kota Makassar, telah mendorong pengembangan kota yang terintegrasi menjadi satu kesatuan sebagai kota metropolitan. Konsep pengembangan ini mendorong pembagian fungsi dan peran Kota Makassar sebagai kota inti dan kawasan perkotaan disekitarnya. Dampak konsep pengembangan ini mengakibatkan perubahan penggunaan lahan yang pada awalnya didominasi lahan pertanian/perdesaan berubah dan berkembang kearah fungsi perkotaan. Sebagai salah satu kota metropolitan penting di Indonesia, kawasan perkotaan ini menerima berbagai bentuk konsep pengembangan kawasan di dalamnya, salah satunya dengan munculnya komunitas berpagar. Pengembangan kawasan perumahan dengan konsep ini muncul karena adanya kebutuhan lingkungan yang aman, lengkap dan bersifat privat untuk kelompok masyarakat menengah ke atas. Komunitas berpagar mulai berkembang pesat pada tahun 2011 ketika Peraturan Presiden No. 55 Tahun 2011 tentang Rencana Tata Ruang Kawasan Perkotaan Makassar, Maros, Sungguminasa, dan Takalar ditetapkan dan penandatanganan kerjasama pengembangan perumahan dengan Real Estate Indonesia dilakukan.

\section{Karakteristik Komunitas Berpagar di Kawasan Perkotaan Mamminasata}

Secara keseluruhan jumlah komunitas berpagar yang teridentifikasi di Kawasan Perkotaan Mamminasata sebanyak 392 unit dengan klasifikasi kelas perumahan menengah keatas, menengah, dan menengah (subsidi) dapat dilihat pada Tabel 1. Karakteristik 
berdasarkan jenis, tipe, dan rentang waktu pembangunan pada Kawasan Perkotaan Mamminasata dapat dilihat pada Gambar 1.

Tabel 2. Karakteristik Perumahan Komunitas Berpagar

\begin{tabular}{lll}
\hline \multicolumn{1}{c}{ Jenis Perumahan } & \multicolumn{1}{c}{ Tipe Perumahan } & \multicolumn{1}{c}{ Kelas Perumahan } \\
\hline 318 Perumahan Mengantong & 1 Tipe Prestige & 85 Kelas Menengah Keatas \\
41 Perumahan Tembusan & 46 Tipe Keamanan Lingkungan & 297 Kelas Menengah \\
33 Perumahan Akses & 69 Tipe Lifestyle & 10 Kelas Menengah (Subsidi) \\
Terbatas & & \\
\hline
\end{tabular}

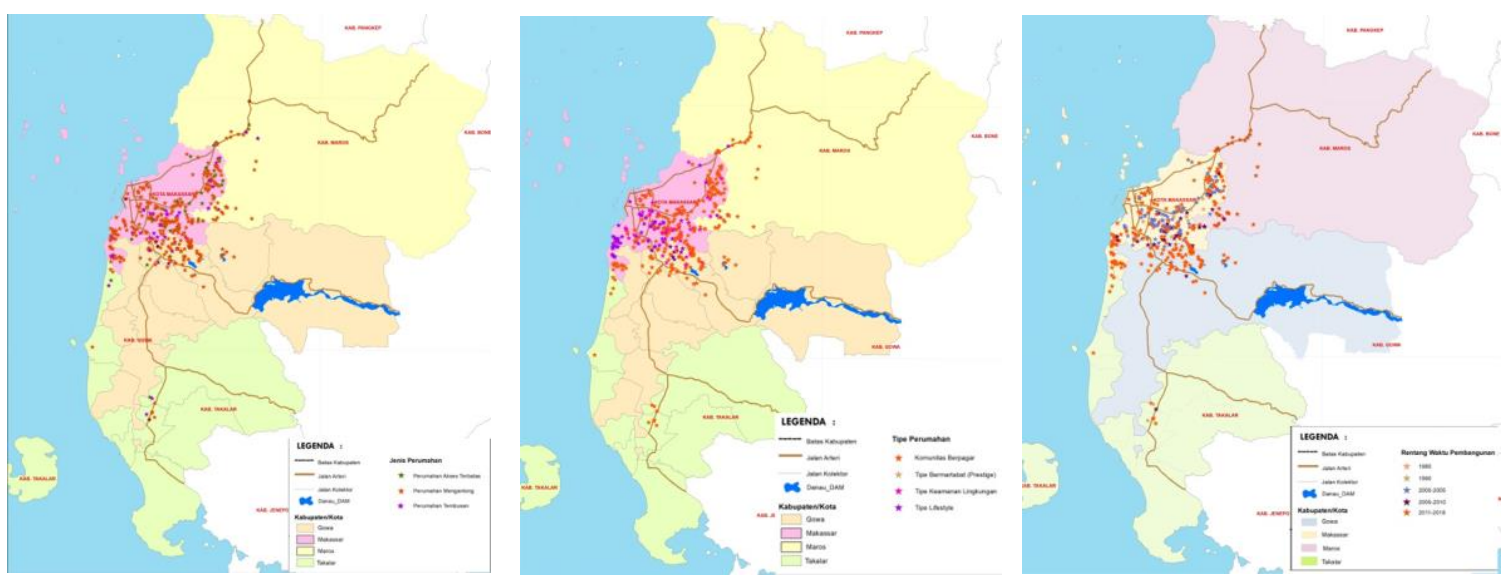

\section{Gambar 1. Tipe dan Rentang Waktu Pembangunan Komunitas Berpagar di Kawasan Perkotaan Mamminasata}

\section{Pola Perkembangan Komunitas Berpagar}

Penyebaran komunitas berpagar di Kawasan Perkotaan Mamminasata terakomodasi oleh rencana tata ruang (lihat Gambar 2) yang dibuat oleh pemerintah, dimana dalam rencana tersebut konsentrasi pusat-pusat permukiman telah ditentukan. Pola penyebaran ini selaras dengan arahan rencana tata ruang dengan kecenderungan pengelompokan komunitas berpagar yang berada di bagian Timur, Barat dan Selatan Kota Makassar. Meskipun pada umumnya pengembangan komunitas berpagar mengikuti rencana, namun beberapa komunitas berpagar dibangun tidak sesuai rencana tata ruang serta membangun dalam zona rawan bencana (lihat Gambar 2).

Pola perkembangan komunitas berpagar di Kawasan Perkotaan Mamminasata tidak sepenuhnya organik, cenderung 'berdiri sendiri' yang berlokasi di peruntukan lahan pertanian (10\% dari total komunitas berpagar) yang tersebar di Kecamatan Barombong (Makassar-Gowa), Kecamatan Moncongloe (Maros), Kabupaten Gowa berada di Kelurahan Jenetalasa, Sunggumanai, Borongloe dan Pangkabinanga dan Kecamatan Galesong Utara (Takalar). Pola ini terkait dengan kemampuan pengembang dalam menguasai lahan dan ketersediaan infrastruktur untuk mengurangi biaya pembangunan perumahan. Namun demikian mayoritas komunitas berpagar dibangun dan dikembangkan tidak pada lahan yang benar-benar kosong jauh dari permukiman atau infrastruktur yang sudah ada di sekitarnya. Masih ada pola penyebaran yang merambat sebagai implikasi perkembangan bagian kawasan perkotaan lainnya dan masih relatif selaras dengan perkembangan fisik kawasan/wilayah sekitar. 

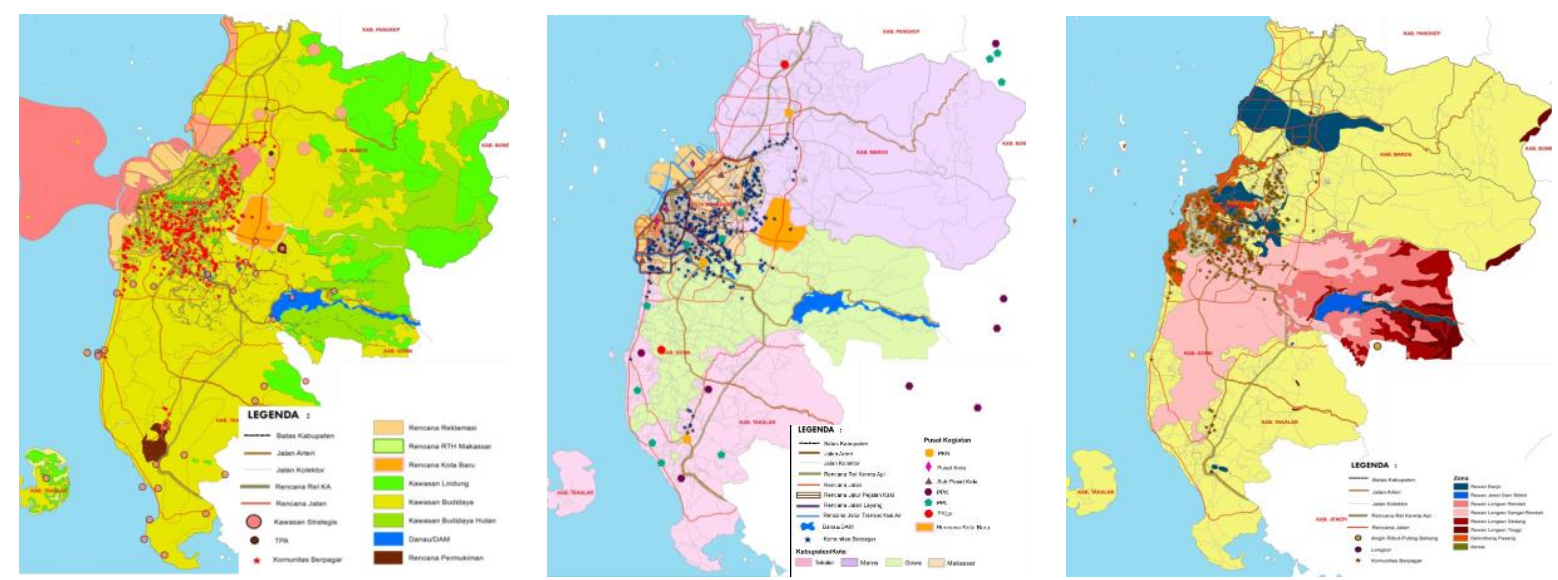

\section{Gambar 2. Peta Sebaran Komunitas Berpagar Berdasarkan Rencana Tata Ruang Wilayah Kota/Kabupaten dan Zona Rawan Bencana di Mamminasata}

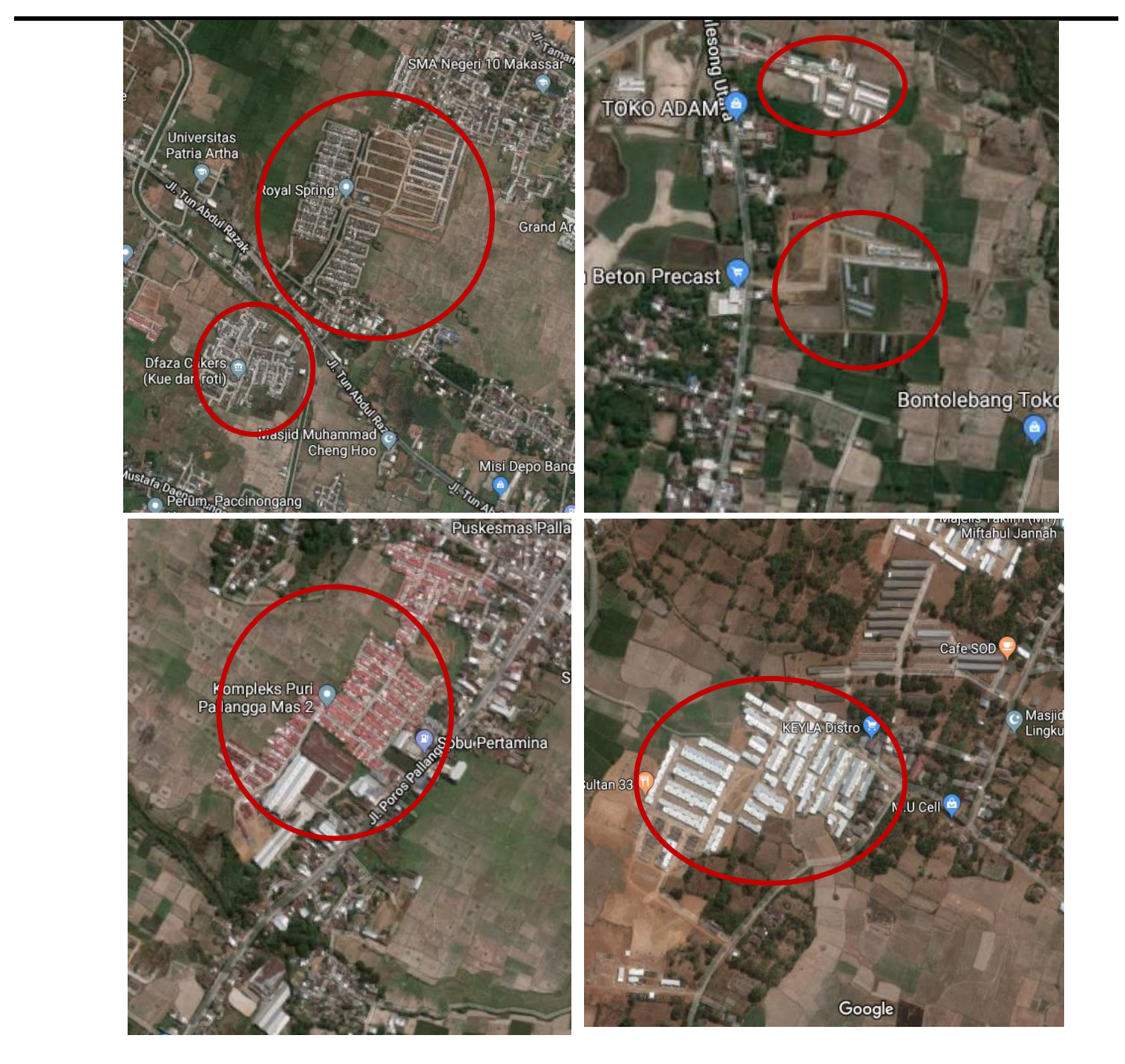

Sumber: Citra Satelit Google Earth dan Google Map, 2019

Gambar 3. Komunitas Berpagar yang Tidak Homogen dengan Penggunaan Lahan Sekitar 
Pengembangan perumahan komunitas berpagar umumnya menggunakan lahan kosong atau lahan pertanian. Perubahan lahan tampak jelas di tahun 2010 khusus untuk lahan permukiman secara umum sebesar 21.327,5 ha atau 9\% dari luas lahan Kawasan Perkotaan Mamminasata meningkat menjadi 25.080,08 atau $10 \%$ dari luas lahan Mamminasata di tahun 2018. Hingga saat ini, komunitas berpagar terkonsentrasi di bagian Timur Kota Makassar (Kecamatan Biringkanaya) yang berbatasan langsung dengan Kabupaten Maros, bagian Selatan Kota Makassar (Kecamatan Panakkukang dan Manggala) yang berbatasan langsung dengan Kabupaten Gowa (Kecamatan Somba Opu) dan di bagian Barat Kota Makassar (Kecamatan Tamalate). Sebaran perkembangan komunitas berpagar di lahan terbangun pada tahun 2005, 2010, dan 2018 dapat dilihat pada Gambar 4.

Perubahan lahan terbangun terus berkembang terutama dibagian kawasan penyangga antara Makassar-Maros, Makassar-Gowa, dan Makassar-Takalar. Berdasarkan perhitungan berbasis Arcgis, lahan terbangun Kawasan Perkotaan Mamminasata pada tahun 2005 sebesar 7\% dan sisanya 93\% merupakan lahan tidak terbangun, di tahun 2010 persentasi lahan terbangun naik menjadi 10\% dan di tahun 2018 lahan terbangun meningkat sebesar $12 \%$.

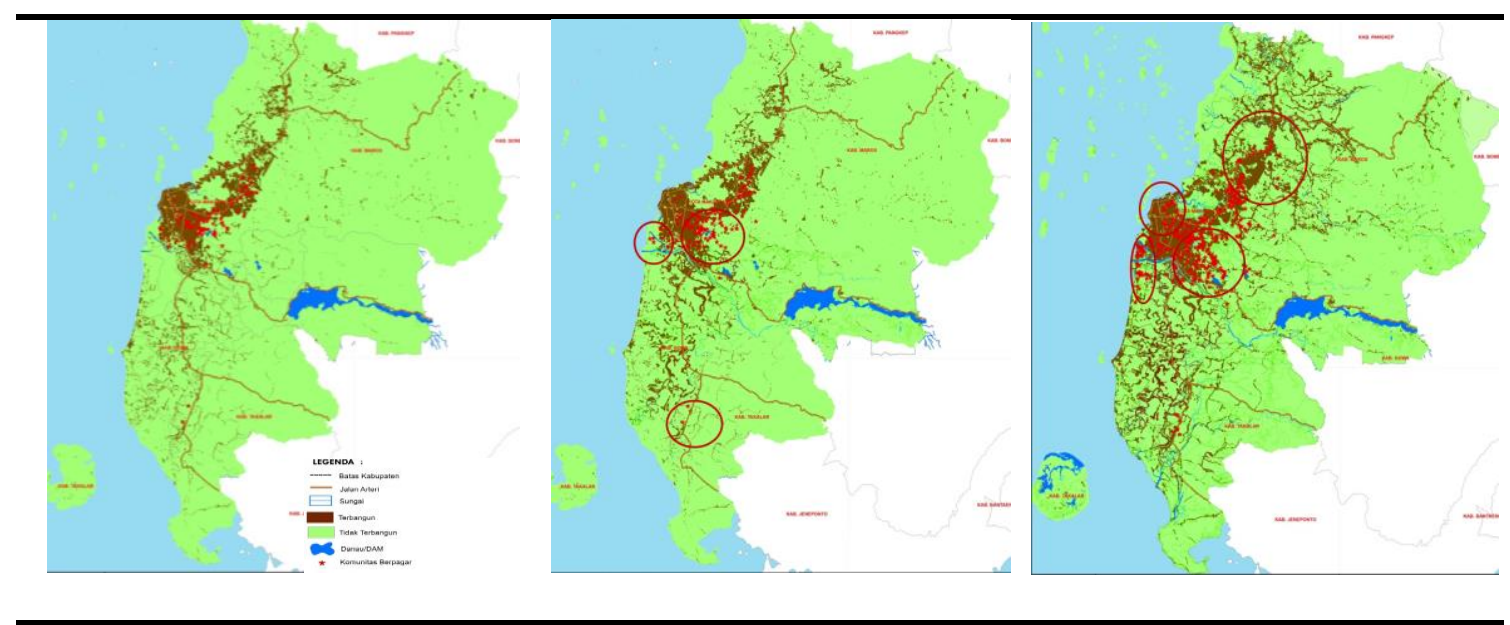

\section{Gambar 4. Perkembangan Komunitas Berpagar dan Perubahan Lahan Terbangun di Kawasan Perkotaan Mamminasata Tahun 2005, 2010, dan 2018}

Perkembangan komunitas berpagar di Kawasan Perkotaan Mamminasata mengarah ke pinggiran Kota Makassar. Hanya 53 perumahan yang berlokasi dekat dengan rute transportasi utama, dan terdapat 31 komunitas berpagar yang berkembang di dekat dengan pusat kegiatan di Kecamatan Panakkukang dan Tamalate (lihat Gambar 5).

Dari aspek fragmentasi spasial, komunitas berpagar memisahkan diri secara fisik dan membuat area/zona tersendiri dengan akses yang terkontrol serta terjaga. Namun komunitas berpagar di Mamminasata memperbolehkan penghuni di luar Komunitas untuk menggunakan fasilitas publik seperti club house, taman, dan lapangan olahraga di dalam perumahan. Pelarangan penggunaan fasilitas di lingkungan komunitas berpagar tidak terjadi.

Berdasarkan hasil observasi, beberapa fasilitas perdagangan seperti minimarket, pasar, dan pusat perbelanjaan/mall mulai berkembang di awal tahun 2011 (sebaran fasilitas dapat dilihat pada Gambar 6). Fasilitas seperti pasar telah lebih dahulu ada, sebelum komunitas berpagar dibangun yang rata-rata berdiri sejak tahun 1990-an, sedangkan untuk fasilitas pusat belanja beberapa dibangun pada tahun 2000-an hingga 
2018 sehingga beberapa diantaranya justru menjadi pemicu berkembangnya komunitas berpagar.

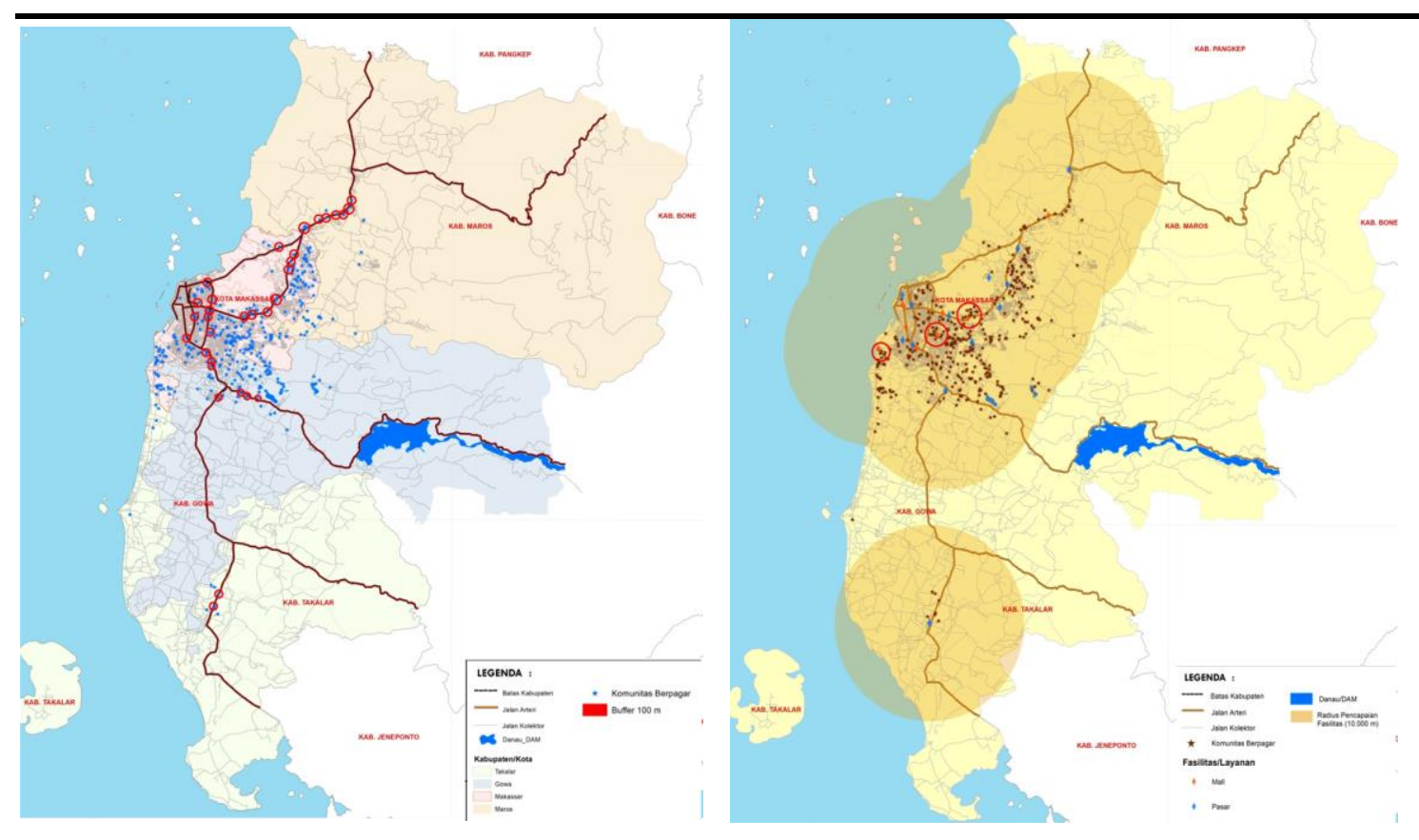

Gambar 5. Sebaran Komunitas Berpagar yang Berlokasi Dekat dengan Rute Transportasi Utama dan Peta Komunitas Berpagar yang Berkelompok Dekat dengan CBD

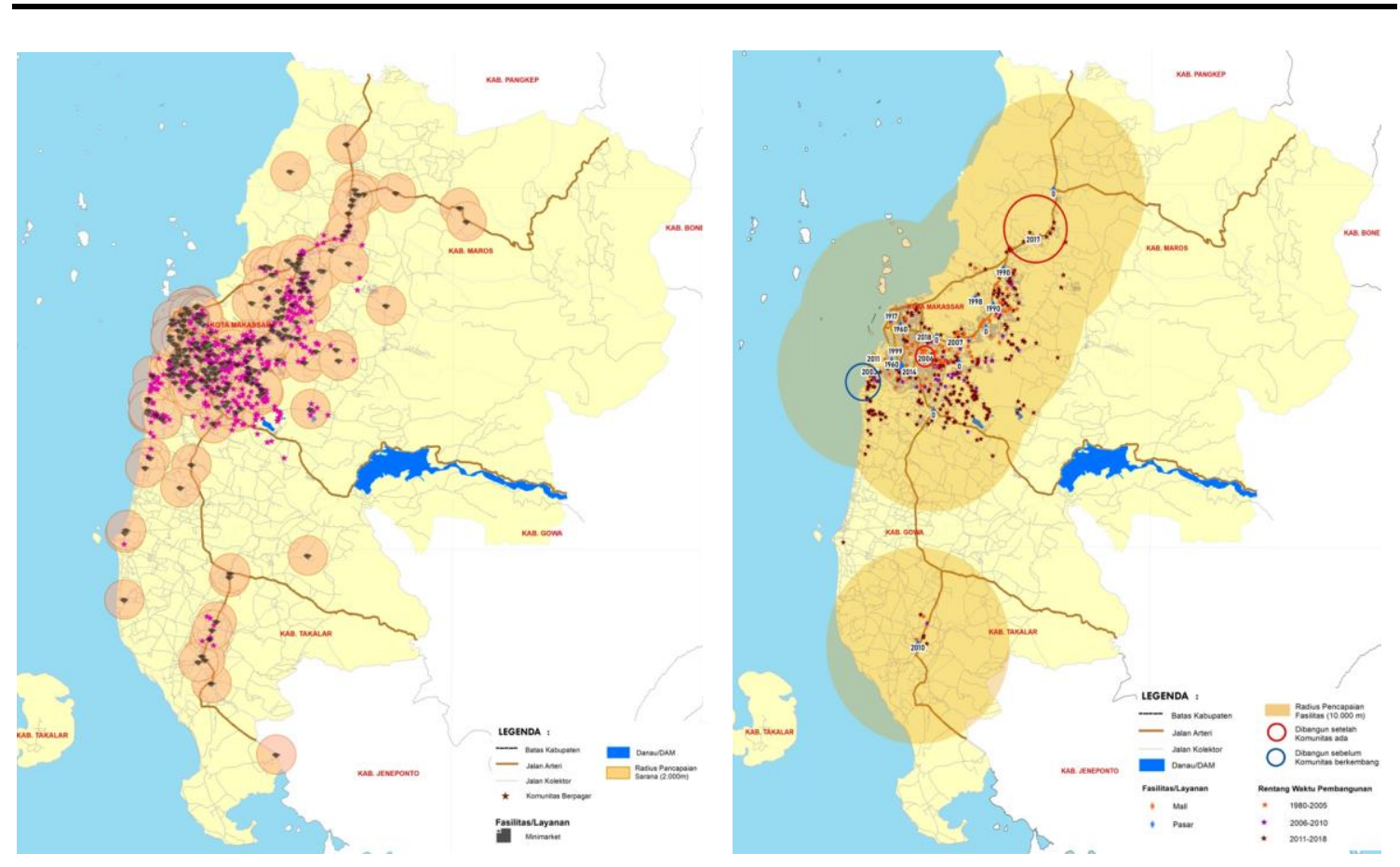

Gambar 6. Peta Sebaran dan Perkembangan Fasilitas Perdagangan (Minimarket, Pasar, dan Pusat Belanja/Mall) di Kawasan Perkotaan Mamminasata 

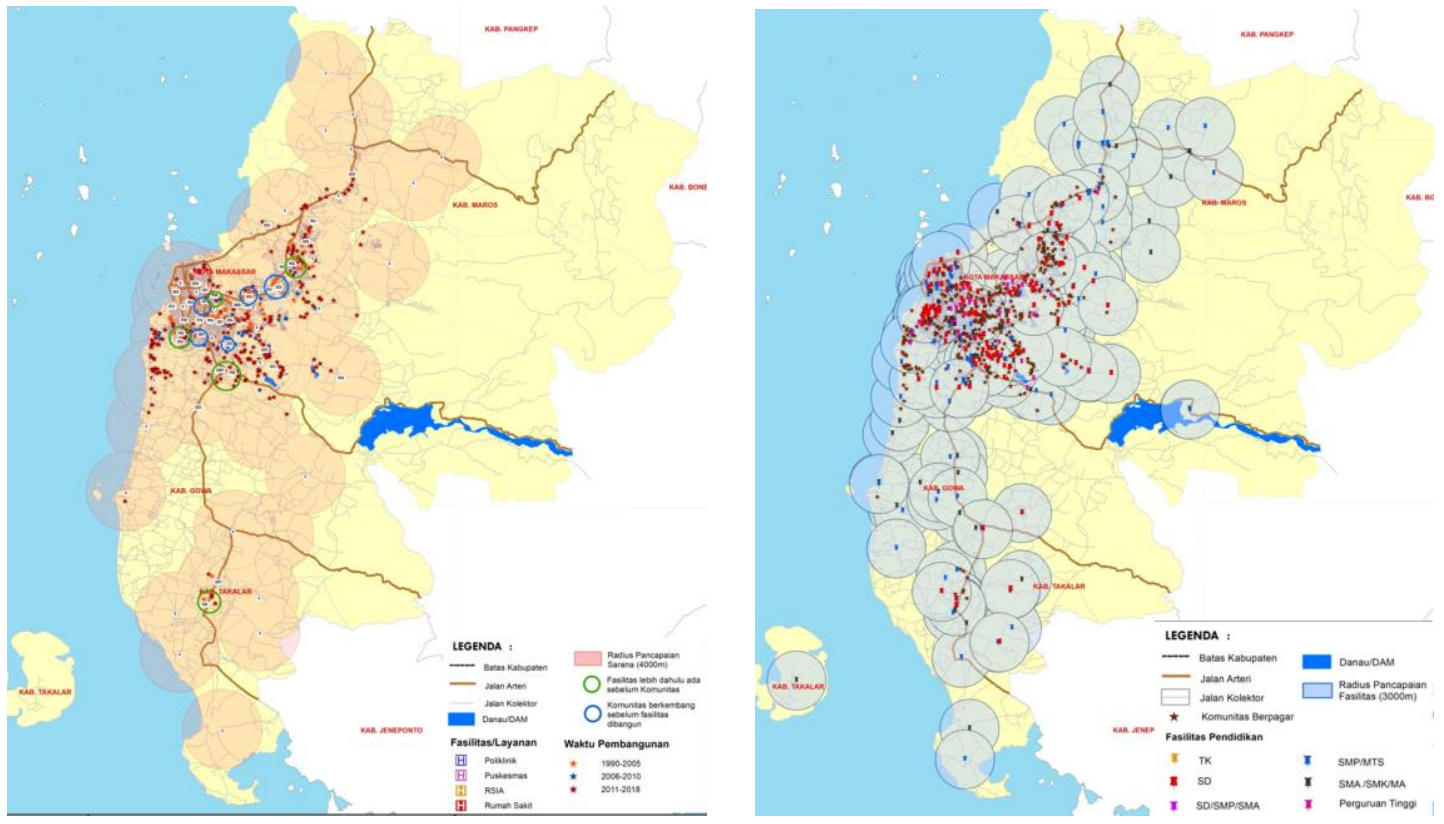

Gambar 7. Peta Sebaran dan Perkembangan Fasilitas Kesehatan dan Pendidikan di Kawasan Perkotaan Mamminasata

Perkembangan fasilitas kesehatan dan pendidikan di Kawasan Perkotaan Mamminasata (Gambar 7) menunjukkan pola yang tersebar di seluruh kawasan perkotaan. Fasilitas kesehatan berupa rumah sakit umum didirikan pada zaman penjajahan jauh sebelum berkembangnya komunitas berpagar, namun untuk rumah sakit swasta dan rumah sakit ibu dan anak (RSIA) mayoritas didirikan setelah komunitas berpagar berkembang. Berbeda dengan fasilitas pendidikan, berdasarkan hasil wawancara menunjukkan bahwa pembangunan kampus baru menjadi pemicu berkembangnya komunitas berpagar. Secara umum fasilitas pendidikan di Kawasan Perkotaan Mamminasata telah cukup terpenuhi, beberapa perumahan juga memiliki taman kanak-kanak, Sekolah Dasar (SD), hingga Sekolah Menengah Atas (SMA), kebanyakan Komunitas berpagar tersebut hanya membatasi akses pada lingkungan perumahan pada jam tertentu.

\section{Dampak Spasial Komunitas Berpagar}

Kecendrungan pengelompokan komunitas berpagar terjadi di bagian Timur dan Selatan Kota Makassar, walaupun sebagian besar komunitas berpagar tersebar secara tidak merata atau sprawl. Komunitas berpagar yang meluas ke arah pinggiran kota mengkonversi lahan pertanian menjadi lahan terbangun, menyebabkan lahan pertanian di pinggiran kota semakin berkurang. Fasilitas perdagangan juga berkembang cukup pesat di sekitar keberadaan komunitas berpagar. Hal ini dapat dilihat dari banyaknya minimarket dan fasilitas lainnya yang tersebar di dalam dan di sekitar komunitas berpagar, beberapa pasar kaget dan rumah makan banyak berkembang di sekitarnya. Karakteristik dan analisis perkembangan komunitas berpagar untuk setiap aspek dapat dilihat pada tabel berikut ini. 
Tabel 3. Dampak Spasial Komunitas Berpagar

\begin{tabular}{|c|c|c|c|}
\hline Kriteria & Indikator & $\begin{array}{l}\text { Perkembangan Komunitas } \\
\text { Berpagar }\end{array}$ & Pemenuhan Indikator \\
\hline \multirow[t]{4}{*}{$\begin{array}{l}\text { Transformasi } \\
\text { Spasial }\end{array}$} & $\begin{array}{l}\text { Kecenderungan } \\
\text { konsentrasi } \\
\text { komunitas } \\
\text { berpagar: } \\
\text { - Tidak } \\
\text { berkelompok } \\
\text { - Tidak } \\
\quad \text { beraturan }\end{array}$ & 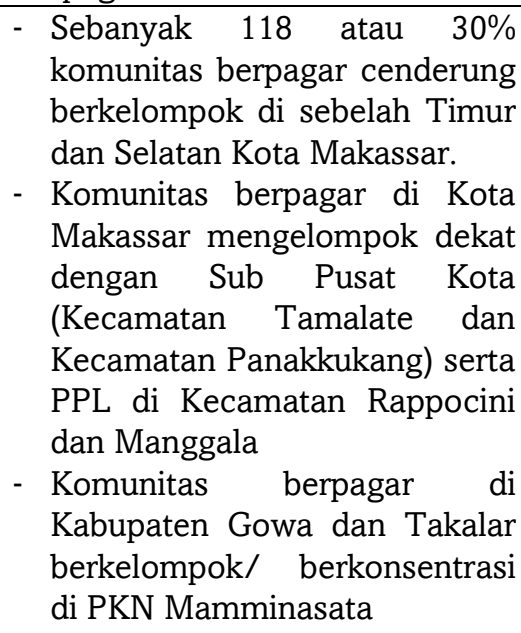 & $\begin{array}{lr}\text { Mayoritas } & \text { komunitas } \\
\text { berpagar } & \text { cenderung } \\
\text { sprawl/tersebar } & \text { tidak } \\
\text { merata. Sebaran ini masih } \\
\text { selaras dengan peruntukan } \\
\text { yang sesuai rencana pola } \\
\text { ruang. } \\
\text { kecenderungan } \\
\text { mengelompok } \\
\text { komunitas berpagar tersebut } \\
\text { sesuai dengan } \\
\begin{array}{lr}\text { dimana petentuan, } \\
\text { sesuai dengan } & \text { kegiatan } \\
\text { ruang (indikator terpenuhi). }\end{array}\end{array}$ \\
\hline & $\begin{array}{l}\text { Perumahan } \\
\text { "berdiri sendiri" } \\
\text { diantara wilayah } \\
\text { tidak terbangun }\end{array}$ & $\begin{array}{l}\text { 10 \% komunitas berpagar berada } \\
\text { di lahan pertanian yang tersebar } \\
\text { di Kecamatan Barombong } \\
\text { (Makassar-Gowa), Kecamatan } \\
\text { Moncongloe (Maros), Kabupaten } \\
\text { Gowa berada di Kelurahan } \\
\text { Jenetalasa, } \\
\text { Borongloe dan Pangkabinanga } \\
\text { dan Kecamatan Galesong Utara } \\
\text { (Takalar) }\end{array}$ & $\begin{array}{l}\text { Walaupun terdapat } \\
\text { komunitas berpagar yang } \\
\text { berlokasi pada pemanfaatan } \\
\text { lahan yang berbeda namun } \\
\text { mayoritas cukup homogen } \\
\text { dengan wilayah sekitar } \\
\text { (peruntukan kawasan } \\
\text { permukiman). (indikator } \\
\text { tidak terpenuhi). }\end{array}$ \\
\hline & $\begin{array}{l}\text { Keberadaan } \\
\text { komunitas } \\
\text { berpagar } \\
\text { mempercepat } \\
\text { atau mendorong } \\
\text { perubahan guna } \\
\text { lahan } \\
\text { disekitarnya }\end{array}$ & $\begin{array}{l}\text { Di tahun } 2010 \text { lahan permukiman } \\
\text { sebesar } 21.327,5 \text { ha atau } 9 \% \text { dari } \\
\text { luas lahan Mamminasata dan di } \\
\text { tahun } 2018 \text { meningkat menjadi } \\
25.080,08 \text { atau } 10 \% \text { dari luas } \\
\text { lahan Mamminasata }\end{array}$ & 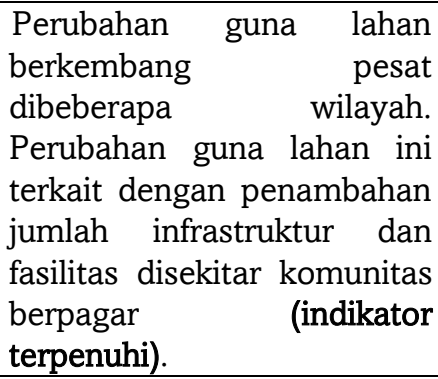 \\
\hline & $\begin{array}{l}\text { Kecenderungan } \\
\text { komunitas } \\
\text { berpagar yang } \\
\text { berlokasi dekat } \\
\text { dengan rute } \\
\text { transportasi } \\
\text { utama dan dekat } \\
\text { dengan pusat } \\
\text { kegiatan }\end{array}$ & $\begin{array}{l}\text { Terdapat } 53 \text { perumahan (13\%) } \\
\text { yang berlokasi dekat dengan rute } \\
\text { transportasi utama, dan } 31(8 \%) \\
\text { dari komunitas berpagar } \\
\text { berkembang dekat dengan pusat } \\
\text { kegiatan di Kecamatan } \\
\text { Panakkukang dan Tamalate }\end{array}$ & $\begin{array}{l}\text { Walaupun perkembangan } \\
\text { komunitas berpagar di } \\
\text { beberapa } r \text { wilayah } \\
\text { berkembang dekat pusat } \\
\text { kegiatan dan jalan utama, } \\
\text { namun mayoritas tersebar } \\
\text { tidak mengikuti jaringan } \\
\text { trasportasi dan pusat } \\
\text { kegiatan yang ada (indikator } \\
\text { tidak terpenuhi). }\end{array}$ \\
\hline $\begin{array}{l}\text { Fragmentasi } \\
\text { Spasial }\end{array}$ & $\begin{array}{l}\text { Perumahan } \\
\text { komunitas } \\
\text { berpagar secara } \\
\text { fisik terpisah } \\
\text { dikelilingi pagar } \\
\text { serta terjaga. }\end{array}$ & $\begin{array}{l}\text { Terdapat } 42(10 \%) \text { komunitas } \\
\text { berpagar perumahan yang tidak } \\
\text { memiliki } \\
\text { penjagaan/keamanan. }\end{array}$ & \begin{tabular}{lrr} 
Mayoritas & \multicolumn{2}{r}{ komunitas } \\
berpagar secara fisik \\
terpisah dan & dikelilingi \\
pagar dengan & sistem \\
keamanan yang & beragam \\
(terpenuhi). & (indikator
\end{tabular} \\
\hline
\end{tabular}




\begin{tabular}{|c|c|c|c|}
\hline \multirow[t]{4}{*}{ Kriteria } & Indikator & $\begin{array}{l}\text { Perkembangan Komunitas } \\
\text { Berpagar }\end{array}$ & Pemenuhan Indikator \\
\hline & & & \multirow[b]{2}{*}{$\begin{array}{l}\text { terpenuhi). } \\
\text { Masyarakat diluar dapat } \\
\text { mengakses fasilitas } \\
\text { komunitas berpagar dengan } \\
\text { cukup mudah (indikator } \\
\text { tidak terpenuhi). }\end{array}$} \\
\hline & $\begin{array}{l}\text { Pelarangan } \\
\text { penggunaan } \\
\text { fasilitas oleh } \\
\text { bukan penghuni }\end{array}$ & $\begin{array}{l}\text { Akses terhadap fasilitas seperti } \\
\text { taman, club house (gym dan } \\
\text { kolam renang) dapat digunakan } \\
\text { oleh masyarakat diluar komunitas } \\
\text { berpagar walaupun harus } \\
\text { membayar dan dibeberapa } \\
\text { Komunitas perlu meninggalkan } \\
\text { identitas diri r pada } \\
\text { satpam/keamanan }\end{array}$ & \\
\hline & $\begin{array}{l}\text { Perumahan } \\
\text { dengan akses } \\
\text { terkontrol. }\end{array}$ & $\begin{array}{l}\text { Mayoritas perumahan }(90 \%) \text {, } \\
\text { memiliki sistem penjagaan yang } \\
\text { cukup ketat, baik yang berupa } 1 \\
\text { sistem keamanan (portalpagar) } \\
\text { maupun yang berlapis seperti } \\
\text { portal, pagar, cctv, penjagaan } \\
\text { keamanan } 24 \text { jam, dan kartu } \\
\text { identitas. }\end{array}$ & $\begin{array}{l}\text { Sistem } \\
\text { komunitas benjagaan } \\
\text { terkontrol dan } \text { terjaga } \\
\text { (indikator terpenuhi). }\end{array}$ \\
\hline \multirow[t]{3}{*}{$\begin{array}{l}\text { Perubahan } \\
\text { Infrastruktur, } \\
\text { fasilitas dan } \\
\text { layanan }\end{array}$} & $\begin{array}{l}\text { Radius } \\
\text { pencapaian } \\
\text { komunitas } \\
\text { berpagar } \\
\text { terhadap } \\
\text { infrastruktur dan } \\
\text { fasilitas di } \\
\text { sekitarnya }\end{array}$ & $\begin{array}{l}\text { - Untuk keterjangkauan fasilitas } \\
\text { minimarket masih terdapat } 20 \\
\text { komunitas berpagar yang } \\
\text { jaraknya cukup jauh dari } \\
\text { fasilitas tersebut, terdapat } 15 \\
\text { komunitas berpagar yang } \\
\text { memiliki minimarket di dalam } \\
\text { area perumahannya. } \\
\text { - Fasilitas seperti pasar rakyat } \\
\text { telah lebih dahulu ada sebelum } \\
\text { komunitas berpagar karena } \\
\text { rata-rata berdiri sejak tahun } \\
\text { 1990-an, sedangkan untuk } \\
\text { fasilitas pusat } \\
\text { perbelanjaan/mall beberapa } \\
\text { dibangun pada tahun 2000-an } \\
\text { hingga } 2018 \text { sehingga beberapa } \\
\text { diantaranya justru menjadi } \\
\text { pemicu berkembangnya } \\
\text { komunitas berpagar. Semua } \\
\text { komunitas berpagar dapat } \\
\text { menjangkau sarana pendidikan. }\end{array}$ & $\begin{array}{l}\text { Perubahan infrastruktur dan } \\
\text { perkembangan fasilitas } \\
\text { karena komunitas berpagar } \\
\text { terjadi di beberapa wilayah, } \\
\text { terutama di kawasan } \\
\text { pinggiran Kota Makassar, } \\
\text { hampir semua fasilitas } \\
\text { seperti perdagangan dan } \\
\text { jasa, pendidikan serta } \\
\text { kesehatan tersebar tidak } \\
\text { jauh dan masih terjangkau } \\
\text { oleh komunitas berpagar } \\
\text { (indikator terpenuhi). }\end{array}$ \\
\hline & $\begin{array}{l}\text { Penciptaan } \\
\text { ruang dengan } \\
\text { kualitas } \\
\text { lingkungan yang } \\
\text { lebih baik dari } \\
\text { sebelumnya }\end{array}$ & $\begin{array}{l}\text { - } \text { Beberapa komunitas berpagar } \\
\text { dekat dengan kawasan kumuh. } \\
\text { - Terdapat indikasi dibeberapa } \\
\text { Kecamatan dimana komunitas } \\
\text { berpagar yang dibangun justru } \\
\text { menyebabkan banjir di } \\
\text { perumahan sekitar (hasil } \\
\text { wawancara). } \\
\text { - Beberapa jalan perumahan } \\
\text { (5\%) masih belum layak (jalan } \\
\text { masih tanah, jalan rusak, dan } \\
\text { jalan berbatu) tersebar di } \\
\text { Kawasan Mamminasata. }\end{array}$ & $\begin{array}{lrr}\begin{array}{l}\text { Sebagian } \\
\text { berpagar }\end{array} & \begin{array}{r}\text { komunitas } \\
\text { memiliki } \\
\text { dampak }\end{array} \\
\text { penciptaan } & \text { ruang derhadap } \\
\text { kualitas } & \text { lingkungannya, } \\
\text { penciptaan } & \text { kualitas } \\
\text { lingkungan yang lebih baik } \\
\text { mayoritas } & \text { terjadi pada } \\
\text { kawasan } & \text { elit/menengah } \\
\text { keatas (indikator terpenuhi). }\end{array}$ \\
\hline & Mengubah pola & komunitas & Perumahan \\
\hline
\end{tabular}




\begin{tabular}{|c|c|c|c|}
\hline Kriteria & Indikator & $\begin{array}{l}\text { Perkembangan Komunitas } \\
\text { Berpagar }\end{array}$ & Pemenuhan Indikator \\
\hline & $\begin{array}{l}\text { jalan seperti: } \\
\text { - jalan terputus } \\
\text { dan tidak } \\
\text { terintegrasi } \\
\text { (penutupan } \\
\text { jalan dan } \\
\text { hambatan } \\
\text { layanan } \\
\text { darurat) } \\
\text { - akses jalan } \\
\text { terbatas. }\end{array}$ & $\begin{array}{l}\text { berpagar merupakan perumahan } \\
\text { mengantong }\end{array}$ & $\begin{array}{l}\text { mengindikasi bahwa jalan di } \\
\text { perumahan tersebut tidak } \\
\text { dapat diakses dengan } \\
\text { mudah oleh masyarakat luar } \\
\text { karena memakai sistem satu } \\
\text { pintu masuk-keluar, namun } \\
\text { beberapa perumahan } \\
\text { memang terletak di } \\
\text { pinggiran kota atau dilahan } \\
\text { yang tidak terbangun } \\
\text { sehingga tanpa melewati } \\
\text { jalan tersebut tidak menjadi } \\
\text { masalah bagi masyarakat } \\
\text { lain (indikator terpenuhi). }\end{array}$ \\
\hline
\end{tabular}

Perkembangan komunitas berpagar cenderung terfragmentasi, tersebar dan tidak beraturan mengikuti penguasaan lahan yang dimiliki oleh sektor swasta. Pola perkembangan ini mengubah tidak hanya secara spasial konfigurasi guna lahan pada kawasan perkotaan tetapi juga munculnya perumahan-perumahan ekslusif yang berbeda dan tidak terhubung dengan perumahan di sekitarnya. Sebagian besar permukiman komunitas berpagar berkembang berdekatan dengan fasilitas-fasilitas publik, berada pada radius pencapaian fasilitas seperti kesehatan, perdagangan dan jasa, serta pendidikan cukup terjangkau, hal ini juga berkaitan dengan komunitas berpagar yang tidak memiliki fasilitas di dalam perumahannya sehingga menyebabkan para penghuni masih bergantung pada fasilitas lain di sekitarnya. Ditinjau dari kualitas lingkungan tidak semua komunitas berpagar memiliki kualitas lingkungan yang lebih baik, terdapat beberapa komunitas berpagar bahkan berdekatan dengan kawasan kumuh dan menjadi penyebab genangan/banjir ke permukiman sekitarnya. Mayoritas konektivitas jalan di komunitas berpagar tertutup karena menerapkan sistem satu pintu sehingga jalan tidak mudah diakses oleh masyarakat lain, namun beberapa dari perumahan tersebut memang terletak di pinggiran kota atau di lahan yang sekitarnya tidak terbangun.

Hampir seluruh indikator dampak spasial komunitas berpagar terpenuhi yang mengindikasikan bahwa keberadaan komunitas berpagar mempunyai kaitan yang erat dengan perubahan spasial kawasan Metropolitan Mamminasata. Terdapat tiga indikator yang tidak dipenuhi yaitu indikator yang terkait keberadaan komunitas berpagar yang cenderung "berdiri sendiri" diantara wilayah tidak terbangun; kecenderungan komunitas berpagar yang berlokasi dekat dengan rute transportasi utama dan dekat dengan pusatpusat kegiatan; dan, pelarangan penggunaan fasilitas oleh bukan penghuni. Temuan ini sedikit berbeda dengan karakteristik perkembangan komunitas berpagar di Kawasan Metropolitasn Johannesburg yang menunjukkan bahwa komunitas berpagar cenderung berlokasi dekat dengan rute transportasi utama dan dekat dengan pusat kegiatan atau pusat kota sehingga kawasan pinggiran kota menjadi kosong (Landman \& Badenhorst, 2012). Dua indikator pertama yang tidak dipenuhi, dipahami sebagai akibat pengembang/developer lebih mengutamakan harga murah dalam mendapatkan tanah dan pertimbangan konsumen yang cenderung memilih tempat tinggal yang relatif sudah ada fasilitasnya. Sementara indikator ketiga lebih disebabkan karena keterbatasan pengelola komunitas berpagar dalam mengendalikan dan melakukan pengawasan lingkungannya. Temuan penelitian ini memperkuat hasil penelitian komunitas berpagar di Nanjing yang menunjukkan adalanya pola, jenis dan karakteristik perumahan komunitas berpagar 
berdasarkan nilai lokasi, harga lahan serta mengkonfirmasi bahwa sangat penting mempertimbangkan karakteristik ekonomi dan sosial warga masyarakat untuk memahami pola diferensiasi sosial-spasial perkotaan (Song \& Liu, 2017). Demikian juga terkait persepsi masyarakat terkait keselamatan dari tindak kriminal terhadap pilihan tempat tinggal dan gaya hidup (Makinde, 2020; Mohamed Salah \& Ayad, 2018; Yönet \& Yirmibeş oğ lu, 2018).

Penelitian ini memperkaya perdebatan hubungan komunitas berpagar dan dampaknya terhadap ruang. Dalam konteks Kota Metropolitan, perubahan guna lahan yang terjadi disekitar perumahan komunitas berpagar cukup signifikan terutama perubahan lahan di kawasan pinggiran kota. Perubahan ini disebabkan karena Kota Makassar sebagai kawasan inti Metropolitan telah dipadati oleh berbagai kegiatan dengan intensitas yang mulai tinggi dan menyebabkan harga lahan menjadi tidak murah. Perubahan guna lahan ini ikut mempengaruhi fasilitas dan layanan seperti yang terjadi di sekitar kawasan inti Kota Makassar (komunitas berpagar dibangun sebelum fasilitas perdagangan dan komersial bermunculan) yang mengindikasikan perkembangan komunitas berpagar juga mendorong munculnya fasilitas-fasilitas layanan seperti perdagangan dan jasa, rumah sakit dan perguruan tinggi. Hasil penelitian ini memperkuat penelitian yang dilakukan oleh Radinal dkk., dan Widiatri dkk. (Radhinal \& Ariyanto, 2017; Widiatri et al., 2014) pada lingkup kawasan, bahwa terjadi polarisasi fungsi-fungsi aktivitas ekonomi yang terjadi di kawasan pinggiran oleh aktivitas ekonomi formal dan informal di sepanjang koridor jalan, meskipun penelitian ini menunjukkan bahwa tidak selalu permukiman komunitas berpagar berkembang mengikuti jaringan jalan yang ada. Penelitian ini juga menunjukkan besarnya peran sektor swasta terhadap terbentuknya komunitas berpagar sebagaimana terjadi di negara sedang berkembang/negara dunia ketiga (Elhadary \& Ali, 2017; Leisch, 2002; Song \& Liu, 2017). Dalam mengatasi kesenjangan dan eksklusifitas, pemerintah dan developer perlu mempertimbangkan berbagai bentuk tingkatan kelas pendapatan jika akan membuat komunitas berpagar sehingga dampak negatif yang di timbulkan dapat diminimalkan.

\section{KESIMPULAN}

Dampak spasial yang terjadi di Kawasan Perkotaan menunjukkan bahwa perkembangan komunitas berpagar menyebabkan terjadinya transformasi spasial karena mendorong perkembangan fisik yang menyebar, tidak berpola, tidak tersebar secara merata/teratur serta mendorong perubahan guna lahan yang signifikan. Ditinjau dari sisi fragmentasi ruang, komunitas berpagar terbukti secara fisik terpisah karena dikelilingi oleh pagar/dinding serta memiliki sistem penjagaan yang sangat terkontrol. Fragmentasi ruang terjadi di lapangan karena mayoritas komunitas berpagar di kelilingi pagar/tembok serta memiliki akses terkontrol, namun pelarangan penggunaan fasilitas publik di dalam komunitas berpagar tidak terjadi. Dari aspek infrastruktur dan fasilitas, keberadaan komunitas berpagar tidak selalu menyebabkan kualitas infrastruktur dan fasilitas lingkungan di sekitarnya lebih baik dari sebelumnya.

\section{DAFTAR PUSTAKA}

Al_Omari, O. M. (2015). The Emergence of the Residential Gated Communities in Jordan. Research Journal of Applied Sciences, Engineering and Technology, 11(3), 293-298. https://doi.org/10.19026/rjaset.11.1719

Blakely, E. J., \& Snyder, M. G. (1997). Fortress America: Gated Communities in the United States. Brookings Institution Press and Lincoln Institute of Land Policy.

Elhadary, Y., \& Ali, S. (2017). A New Trend In Urban Housing: Gated Communities In Khartoum, Sudan. $\begin{array}{lllll}\text { American Journal of Sociological Rearch, } & \text { 41), }\end{array}$ https://doi.org/10.5923/j.sociology.20170701.07

Grant, J., \& Mittelsteadt, L. (2004). Types of gated communities. Environment and Planning B: Planning and Design, 31, 913-930. https://doi.org/10.1068/b3165 
Heryanto, B. (2013). Komunitas Pintu Gerbang : Pengaruh Tipomorfologi Permukiman terhadap Pola Spasial Kota. Temu Ilmiah IPLBI 2013, B13-B18.

Landman, K., \& Badenhorst, W. (2012). The impact of gated communities on spatial transformation in the Greater Johannesburg area. In The South African Research Chair in Development Planning and Modelling, School of Architecture and Planning, University of Witwatersrand.

Le Goix, R. (2005). Gated Communities: Sprawl and Social Segregation in Southern California. Housing Studies, 20(2), 323-343. https://doi.org/10.1080/026730303042000331808

Leisch, H. (2002). Gated Communities in Indonesia. Cities, 19(5), 341-350. https://doi.org/10.1016/S02642751(02)00042-2

Mahgoub, Y., \& Khalfani, F. (2012). Sustainability of Gated Communities in Developing Countries. Developing Country Studies, 2(6), 53-64.

Makinde, O. O. (2020). The Correlates of Residents' Perception of Safety in Gated Communities in Nigeria. Social Sciences \& Humanities Open, 2(1), 100018. https://doi.org/10.1016/j.ssaho.2020.100018

Mohamed Salah, N., \& Ayad, H. M. (2018). Why people choose gated communities: A case study of Alexandria metropolitan area. Alexandria Engineering Journal, 574), 2743-2753. https://doi.org/10.1016/j.aej.2017.10.008

Radhinal, Y., \& Ariyanto, A. (2017). Koeksistensi Dualisme Ekonomi Di Kawasan Metropolitan Mamminasata. Plano Madani : Jurnal Perencanaan Wilayah Dan Kota, 6(1), 97-107. https://doi.org/10.24252/planomadani.6.1.9

Rafiq, N. M. (2015). Emergence of Gated Communities and Their Socio-spatial Impacts on Urban Areas: The Case of Kileleshwa Neighbourhood in Nairobi, Kenya. University of Nairobi.

Roitman, S. (2012). Gated Communities: Definition, Causes and Consequences. Urban Design and Planning, 163, 31-38. https://doi.org/10.1680/udap.2010.163.1.31

Roitman, S., \& Recio, R. B. (2019). Understanding Indonesia's Gated Communities and Their Relationship with Inequality. Housing Studies, O(0), 1-25. https://doi.org/10.1080/02673037.2019.1636002

Silva de Araujo, A., \& Pereira de Queiroz, A. (2018). Spatial Characterization and Mapping of Gated Communities. International Journal of Geo-Information, 7, 1-22. https://doi.org/10.3390/ijgi7070248

Song, W., \& Liu, C. (2017). Spatial Differentiation of Gated Communities in Nanjing. International Journal of Urban Sciences, 21(3), 312-325. https://doi.org/10.1080/12265934.2017.1307780

Widiatri, R. A. (2014). Dinamika perubahan sosial di kawasan mamminasata - provinsi sulawesi selatan. Institut Pertanian Bogor.

Widiatri, R. A., Dharmawan, A. H., \& Kinseng, R. A. (2014). Pengaruh Pembangunan Mamminasata Terhadap Perubahan Sosial Ekonomi Dan Ekologi Pada Masyarakat Lokal. Jurnal Sosiologi Pedesaan, 103-114. https://doi.org/10.22500/sodality.v2i2.9418

Yönet, N. A., \& Yirmibeş oğ lu, F. (2018). Why People Prefer to Live in Gated Communities in Istanbul? Current Urban Studies, 06, 180-195. https://doi.org/10.4236/cus.2018.61010 